\title{
CHMP2A wt Allele
}

National Cancer Institute

\section{Source}

National Cancer Institute. CHMP2A wt Allele. NCI Thesaurus. Code C54366.

Human CHMP2A wild-type allele is located within $19 q$ and is approximately $4 \mathrm{~kb}$ in length.

This allele, which encodes charged multivesicular body protein $2 \mathrm{a}$, plays a role in the regulation of protein sorting and assembly in the formation of multivesicular bodies. 